\title{
A Estrada de Ferro: crescimento econômico e urbano num município brasileiro do Sul de Minas Gerais - Varginha, 1882-1920
}

\section{The Railroad: Economic and urban growth in a Brazilian municipality in the South of Minas Gerais - Varginha, 1882-1920}

\author{
Natânia Silva Ferreira \\ Doutoranda do Programa de Desenvolvimento Econômico da \\ Universidade Estadual de Campinas, Brasil \\ Bolsista CAPES \\ https://orcid.org/0000-0001-7294-1959 \\ natania.silvaferreira@gmail.com
}

Fecha de recepción: 28 de marzo del 2018

Fecha de aceptación: 10 de mayo del 2018

Disponible en línea: 27 de junio del 2018

\begin{abstract}
Sugerencia de citación: Silva Ferreira, N. (2018). A Estrada de Ferro: crescimento econômico e urbano num município brasileiro do Sul de Minas Gerais - Varginha, 18821920. tiempo\&economía, 5(2), 59-87, doi: http://dx.doi.org/10.21789/24222704.1311
\end{abstract}

\section{RESUMO}

Entre o final do século XIX e o início do século XX, diferentes regiões do Brasil passaram por transformações sociais, urbanas e econômicas. Tais transformações tiveram como motor, dentre outros, um importante serviço, meio de transporte e de comunicação: a estrada de ferro. As ferrovias chegaram nas mais diversas localidades, encurtando distâncias, transportando pessoas e mercadorias. $\mathrm{O}$ objetivo central deste artigo é o de compreender a chegada da estrada de ferro num município do interior brasileiro: Varginha, situado no Sul do Estado de Minas Gerais. Com a utilização de fontes manuscritas, impressas e referências bibliográficas, foi possível compreender que a passagem da estrada de ferro pelo município contribuiu com o crescimento urbano e econômico varginhense. 
Palavras-chave: Varginha, ferrovia, transformações urbanas, transformações econômicas, história econômica

Códigos JEL: N76, R42

\section{ABSTRACT}

Between the end of the nineteenth century and the beginning of the twentieth century, different regions of Brazil underwent social, urban and economic transformations. These transformations were driven by, among others, an important service, means of transport and communication: The railroad. The railroads arrived in different locations, shortening distances, transporting people and goods. The central objective of this paper is to understand the arrival of the railroad in a municipality in the Brazilian interior: Varginha, located in the south of the State of Minas Gerais. With the use of handwritten fonts, printed sources and bibliographical references, it was possible to understand that the passage of the railroad through the municipality contributed to the urban and economic growth of Varginha.

Keywords: Varginha, railroad, urban transformations, economic transformations, economic history

JEL Codes: N76, R42. 


\section{Introdução: a formação do Sul de Minas Gerais e o surgimento do município de Varginha}

A passagem do século xıx para o século xx foi um período de transformações urbanas e crescimento econômico para grande parte do Brasil. Com acordos financeiros entre Campos Salles e credores estrangeiros (1898-1902), abriu-se um projeto político de modernização e urbanização do país (Saes, 2008, pp. 188-189).

Dentro deste contexto, é possível destacar alguns casos específicos. O ciclo da borracha se constitui num exemplo de economia particular que possibilitou crescimento econômico do Amazonas, especialmente em Manaus, e do Pará, sobretudo em Belém (Ferreira, 2005, cap. 3; Bueno, 2012). Na Bahia, o cacau auxiliou na formação de uma economia de exportação específica do Estado (Almeida, 2009). No Rio Grande do Sul houve também o desenvolvimento de uma economia própria, baseada na pecuária (Herrlein, 2000). No sudeste do país, São Paulo desenvolveu uma economia cafeeira muito relevante, a atividade que mais contribuiu para o aumento das exportações brasileiras na passagem do século xIx para o xx (Cano, 1975; Dean, 1977; Silva, 1980; Mello, 1986). Na época, a Zona da Mata de Minas Gerais também contou com uma economia cafeeira de exportação (Lima, 1977).

De forma particular, diferentes partes do Brasil passavam por um processo de urbanização e crescimento econômico, com auxílio de atividades agropecuárias.

Naquele cenário, de transformações urbanas e econômicas às quais o Brasil passava na passagem do século xIx para o século xx, o Sul de Minas Gerais ${ }^{1}$ recebeu influências da expansão da economia cafeeira, mais especificamente, na segunda década do século $x x$, quando as exportações passaram a aumentar.

A região do Sul de Minas Gerais tornou-se uma divisão administrativa da Província mineira em 1789, tendo sido emancipada a paróquia de Campanha da Princesa naquele ano. ${ }^{2}$ Localizada inicialmente na Comarca do Rio das Mortes, Campanha tornou-se a sede da Comarca do Rio Sapucaí a partir de 1833, tendo suas fronteiras delimitadas ao norte pelo Rio Grande e ao sul e sudeste pela serra da Mantiqueira. ${ }^{3}$

Assim, o território que inicialmente abrigou o Sul de Minas teve começo com a emancipação de Campanha, município que foi desmembrado na primeira metade do século xIX nas cidades de Baependy (1814), Jacuhy (1814), Pouso Alegre (1831), Lavras (1831), Jaguary (1840) e Itajubá (1848). A dinâmica da região avançou em relação à existente na urbanização da área mineradora e, inicialmente, foi baseada na agricultura e no comércio de abastecimento (Lenharo, 1993).

1 Sobre a divisão do Estado de Minas Gerais, é possível recorrer a Wirth (1982), Paiva \& Godoy (2002).

2 Antes dessa época, o Sul de Minas já apresentava importância como rota de comércio e como produtor de gêneros de abastecimento para outras regiões do Brasil, como a da corte. Segundo Furtado (1963, pp. 114-115), "a cidade do Rio representava o principal mercado de consumo do país e os hábitos de consumo de seus habitantes se haviam transformado substancialmente a partir da chegada da corte portuguesa. O abastecimento desse mercado passou a constituir a principal atividade econômica dos núcleos de população rural que se haviam localizado no sul da província de Minas como reflexo da expansão da mineração".

3 A Comarca do Rio das Mortes havia sido emancipada da área mineradora central, com a fundação de sua sede em São João D’El Rey no ano de 1713.

tiempo\&economía

Vol. 5 N. ${ }^{\circ} 2$ - Julio - Diciembre del 2018

p. 61 
O mapa 1 mostra a localização atual de Varginha e do Sul de Minas Gerais no Estado, bem como o posicionamento de alguns dos municípios citados acima. Ainda, é possível notar os Estados que se situam próximos da região sul-mineira.

Mapa 1. A localização de Varginha no Sul de Minas Gerais e a localização da região sul-mineira no Estado

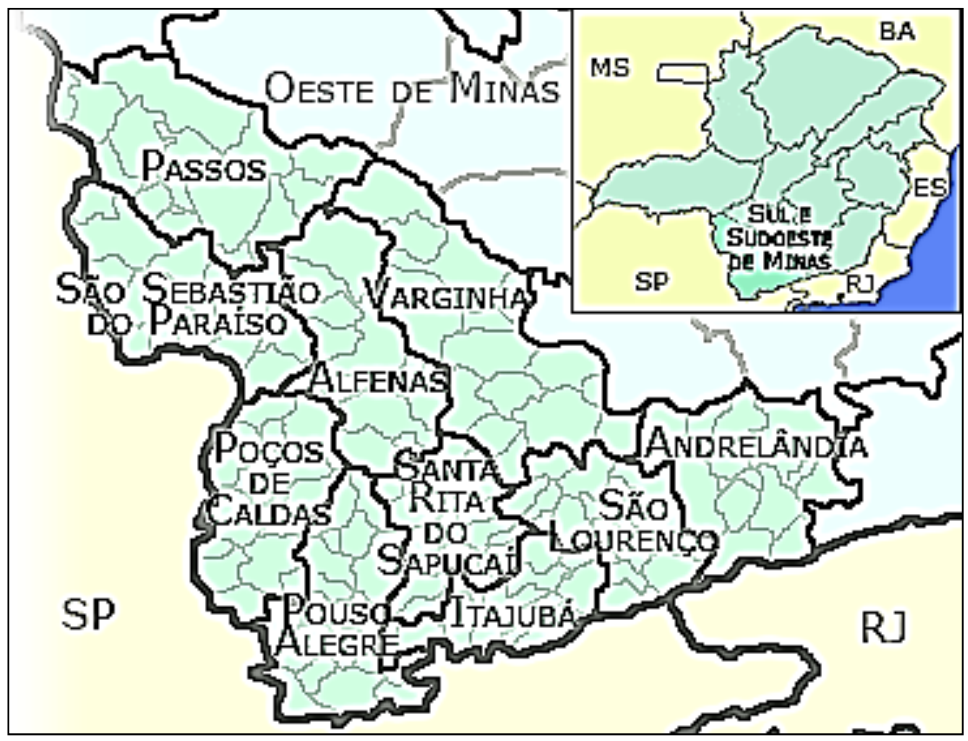

Fonte: http://suldemg.blogspot.com.br/2010/11/mapa-do-sul-de-minas.html.

Acesso em 10/03/2018. No quadro em destaque, onde se lê MS (Mato Grosso do Sul), leia-se GO (Goiás).

A base econômica regional -a agricultura e o comércio de abastecimento- foi rompida, embora não totalmente, entre o final do século xIx e o início do xx, com a introdução da cafeicultura e o processo de urbanização em curso.

O produto mais valioso de exportação de Minas Gerais estabelecia a razão pela qual tanto a Zona da Mata como o Sul dominaram a política do Estado durante a Primeira República (Wirth, 1982, p. 81). ${ }^{4}$ No Sul mineiro:

juntamente à ampliação da população... era nítido o crescimento do número de cidades. Alfenas, Boa Esperança, Três Corações e Varginha, por exemplo, faziam parte de uma primeira fase de emancipação de municípios, entre as décadas de 1860 e 1880, como resultado da introdução do café na região (Saes, Cosentino e Gambi, 2012, p. 31). ${ }^{5}$

4 Apesar da importância do café para Minas Gerais de fins do século XIX e inícios do século XX, é importante ressaltar que a cafeicultura não foi a única atividade regional. Segundo Iglésias (1982), "fala-se em Minas Gerais, quando na verdade sua fisionomia era -como é ainda hoje- muito diversificada" (p. 137). De acordo com Wirth (1982, p. 43) "as paisagens de Minas Gerais, consequentemente, oferecem diferentes leituras ao historiador. As distintas partes de Minas Gerais contaram com atividades econômicas diferentes nos séculos XIX e XX. "O Triângulo tomou forma como uma moderna economia agropecuária a partir da década de $1880 \ldots$... O Norte, ao contrário, seguiu o curso da economia de estâncias do século XVII, salvo uma corrida de diamantes (depois de 1830)... O Oeste exportou gado para o sul" (Wirth, 1982, p. 43).

5 Embora seja dada certa relevância para o café na economia do Sul de Minas Gerais, vale lembrar que na região, na transição para o século XX, outras atividades econômicas se faziam importantes: Alfenas, Guaxupé, Machado e Três Pontas, por exemplo, foram cidades sul-mineiras que se dedicaram não somente à produção cafeeira, mas também à pecuária e 
Assim, Varginha foi emancipada do município de Três Pontas no ano de 1882 e daquele período até o início do século $x x$, passou por transformações que fizeram com que se tornasse uma das principais cidades do Sul de Minas Gerais: os primeiros projetos sobre escolas públicas surgiram por volta da metade da década de 1880 (Ata da Câmara Municipal de Varginha ACMV-,1884, p. 22), a elevação à sede de Comarca ocorreu em 1890 (ACMV ${ }^{6}, 1890$, p. 18), a estrada de ferro Muzambinho começou a passar pelo município no ano de 1892, tendo gerado relevante movimentação na cidade em fins de 1891 (ACMV, 1891, p. 40). Quando se iniciou o século $x x$, Varginha contava com elementos importantes para seu processo de urbanização: as casas comerciais, as primeiras fábricas e os bancos; teatro, clube recreativo e cinema; água potável, telefone e energia elétrica; eram elementos que, juntamente com os que surgiram no final do século XIX, faziam de Varginha um município de destaque no Sul de Minas Gerais (Ávila, 1983; Sales, 2003).

O processo de urbanização ao qual o Brasil e Minas Gerais passaram na mudança do século XIX para o século xx também ocorreu em Varginha, embora de forma particular.

Portanto, o objetivo central deste texto é o de analisar a chegada de um relevante serviço para a economia varginhense: a ferrovia. Em 1892, uma estação da Companhia Estrada de Ferro Muzambinho -que não havia sido planejada para passar por Varginha- foi inaugurada na cidade.

Para o cumprimento do objetivo central, este artigo conta com quatro seções: a primeira servirá para compreensão da chegada do serviço da ferrovia no Sul de Minas Gerais, com destaque para as mercadorias que eram transportadas. Na seção dois, o objetivo será analisar as principais atividades econômicas que estiveram presentes na formação do município de Varginha. Na seção três, serão abordadas as transformações urbanas e econômicas às quais o município varginhense passou, em decorrência da chegada da estrada de ferro. A seção quatro trás as Considerações finais sobre o tema.

As principais fontes para o desenvolvimento deste artigo são: Atas da Câmara Municipal de Varginha -ACMV-, presentes no Museu Municipal da cidade-MMV-, inventário post-mortem de uma personagem varginhense, depositado no Arquivo do Judiciário da Comarca de Varginha -AJCV-, registros de imóveis do município, que se encontram no Cartório de Registros de Imóveis de Varginha; e os Almanachs Sul-Mineiros (para 1874 e 1884), de autoria de Bernardo Saturnino da Veiga.

O recorte temporal é marcado entre 1882 e 1920. O início da investigação envolve o ano de 1882 porque foi em 17 de dezembro de 1882 que ocorreu a primeira reunião da Câmara Municipal de Varginha, onde foram escolhidos os vereadores que conduziriam o processo de formação do novo município do Sul mineiro.

O final do estudo foi datado em 1920 porque esta década constitui um período de transformações para economia brasileira que, de certa forma, podem ter refletido na sociedade varginhense. Segundo Wilson Cano,

demais agriculturas, como a do milho, feijão, arroz e fumo, dentre outras. Sobre a cafeicultura no Sul de Minas Gerais da passagem para o século XX, conferir: Martins (2016).

6 Dentre trabalhos com atas de Câmara, conferir: Ferreira (2017, cap. 2).

tiempo\&economía

Vol. 5 N. 2 - Julio - Diciembre del 2018 
A década de 1920, para o Brasil, representa um processo de transição econômica e social, a partir do chamado modelo primário exportador, rumo a um novo padrão de acumulação, o do crescimento para dentro... as transformações econômicas -mas não somente elas- nela ocorridas [na década de 1920] tiveram importante papel nas principais transformações de cunho social (Cano, 2012, p. 898).

\section{As ferrovias no Sul de Minas Gerais: expansão do transporte de mercadorias}

Segundo Hobsbawm, sobre a ferrovia na "Era dos Impérios": "A ferrovia e a navegação a vapor haviam reduzido as viagens intercontinentais ou transcontinentais a uma questão de semanas, em vez de meses... e em breve as tornaria uma questão de dias" (Hobsbawm, 2016, p. 30). ${ }^{7}$

Uma região vê sua economia transformar-se a partir da chegada da estrada de ferro: ${ }^{8}$ encurtando as distâncias entre as localidades, as ferrovias servem para o transporte de pessoas e de mercadorias; se constituem num meio de comunicação social e geram trabalho nas localidades em que passam. ${ }^{9}$

No Sudeste do Brasil, as estradas de ferro chegaram com auxílio da economia cafeeira, sobretudo em São Paulo. ${ }^{10} \mathrm{~A}$ burguesia do café precisava das ferrovias para a maior qualidade do transporte do produto que gerava crescimento econômico para a Província.

Em Minas Gerais, contando com dinâmica economia cafeeira, a Zona da Mata foi a primeira região a contar com a introdução das ferrovias; detendo, em 1884, aproximadamente $60 \%$ da rede ferroviária mineira, o que equivalia a 1.006 quilômetros (Blasenhein, 1996, pp. 81-110). ${ }^{11}$ A Estrada de Ferro Leopoldina avançou naquela região, além de outras pequenas companhias que foram incorporadas a ela. Além desta, a Zona da Mata contava com a União Mineira, com a Central do Brasil, que partia do Rio de Janeiro e chegava a Ouro Preto, capital da Província mineira, e com a Companhia Estrada de Ferro Oeste de Minas. ${ }^{12}$

No Sul de Minas, as ferrovias chegaram por volta de 1880, por meio de quatro empresas: Estrada de Ferro Rio Verde, que depois passou a ser chamada de Minas e Rio, Viação Férrea Sapucaí, Estrada de Ferro Muzambinho e Companhia Mogiana de Estradas de Ferro, está originária de São Paulo. ${ }^{13}$

7 Para um entendimento acerca do debate internacional sobre ferrovias, ver: Fishlow (1965), Fogel (1964).

8 Sobre ferrovias na América Latina, conferir: Nunes (2007), Lacerda (2009), Correa (2012), Kuntz (2015).

9 A respeito do transporte ferroviário em diferentes localidades do Brasil, consultar: Queiroz (2004), Oliveira (2007), Maia (2009), Goulart e Queiroz (2011), Faleiros e Nunes (2011).

10 Sobre as ferrovias em São Paulo na passagem para o século XX, vale conferir: Saes (1981).

11 Acerca de gastos com infraestrutura de transportes em Minas Gerais da Primeira República, incluindo o transporte ferroviário, ver: Godoy, Horta, Barbosa (2017).

12 Para detalhes sobre a economia da Zona da Mata, consultar: Lanna (1985) e Pires (2004).

13 Sobre ferrovias no Sul de Minas da passagem para o XX, conferir: Silva (2012). Para ferrovias no Sul de Minas do início do século XX, ver: Silva (2018). 
A falta de um centro irradiador para o transporte fez com que, a princípio, no Sul mineiro, houvesse uma integração de suas ferrovias com mercados exteriores, e não entre as próprias cidades da região (Saes et al., 2010).

O mapa 2 mostra as cidades pelas quais passavam as ferrovias no Sul de Minas Gerais em 1890. Em Varginha, uma estação da Estrada de Ferro Muzambinho foi inaugurada no ano de 1892.

Mapa 2. Localização das ferrovias no Sul de Minas Gerais, 1890

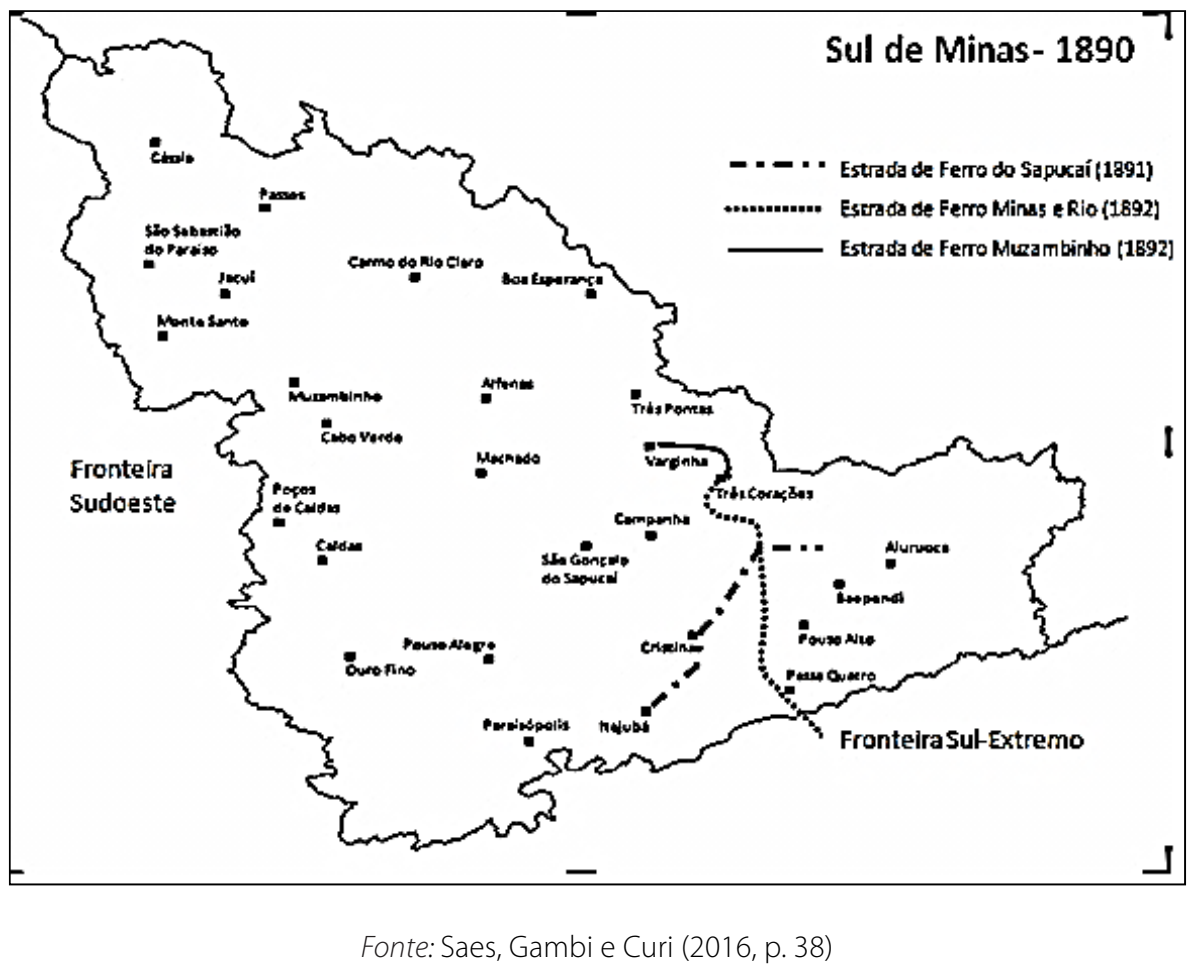

Das quatro estradas de ferro que passaram pelo Sul de Minas Gerais entre o final do século XIx e o início do século xx, a mais antiga foi a Estrada de Ferro Minas e Rio, na época Estrada de Ferro Rio Verde. A base de sua concessão ocorreu quando a Assembleia de Minas Gerais autorizou, por meio da lei 2.062, de 4 de outubro de 1874, o presidente da Província a conceder garantia de juros de $4 \%$ sobre o capital de 14 mil contos de réis para a construção da ferrovia (Silva, 2012, p. 16).

A Minas e Rio foi inaugurada em 1884 e era formada por três ramais e três seções. Seus concessionários eram o Barão de Mauá e o Brigadeiro José Vieira Couto de Magalhães. Barão de Mauá foi pioneiro das obras de estradas de ferro brasileiras, tinha projetos de integração regional, que ligassem o Rio de Janeiro a São Paulo. José Vieira Couto Magalhaes era militar, nascido na cidade mineira de Diamantina, tendo presidido Províncias brasileiras, como Goiás e Minas Gerais (Silva, 2012, p. 114)

Embora intitulada Minas e Rio, sua linha partia de Cruzeiro no interior de São Paulo, e por onde já passava o ramal da Estrada de Ferro Dom Pedro II. Quase desnecessário é dizer o quão 
forte era estar no jogo político para que se obtivesse uma concessão ferroviária e sua garantia de juros, ou fosse exercida influência em traçados pouco técnicos (Silva, 2012, p. 116).

O projeto original da Minas e Rio indicava que a estrada partisse do Rio de Janeiro, mas análises posteriores mostraram maior vantagem se o ponto de partida fosse São Paulo. (Costa, 1996, p. 46, nota 14 apud Silva, 2012, p. 116). Em Minas Gerais, a Minas e Rio passava por Pouso Alto, Passa Quatro, São Lourenço, entre outros, tendo seu ponto final em Três Corações. Até 1910, a estrada de ferro possuía 16 estações entre Minas Gerais e São Paulo (Silva, 2012, pp. 116-117).

A Estrada de Ferro e depois Companhia Viação Férrea Sapucaí foi organizada entre 1887 e 1888, tendo entrado em operação em 1891 e com sede no Rio de Janeiro. Possuía 308 acionistas no ano 1888 (Silva, 2012, p. 125). O café era mercadoria de destaque em alguns pontos, como Jacutinga e Ouro Fino. Com o tempo, a ferrovia incorporou inúmeras concessões. De seu rendimento, considerando passageiros e mercadorias, no ano de 1893, a maior parte era devido o transporte de mercadorias, em todas as oito estações em que passava: cerca de 74 contos com o transporte de passageiros e cerca de 182 contos com o transporte de mercadorias. ${ }^{14}$

Sobre a Estrada de Ferro Muzambinho, que possuía estação em Varginha, vale ressaltar que foi em agosto de 1887 que a lei estadual 3.420 concedeu privilégio para a construção da estrada. Esta deveria partir da divisa de São Paulo com Minas Gerais e terminar no Sul do Estado mineiro (Silva, 2012, p. 132).

Existiam dois ramais e três seções: o primeiro ramal era o de Campanha, que ligava-se a localidades como Cambuquira e Águas Virtuosas do Lambari, estâncias hidrominerais do Sul mineiro. O outro ramal, subdividido em duas seções, era chamado Prolongamento de Três Corações ou Linha do Tronco, e ligava-se à Varginha e Alfenas, dentre outras cidades. O Prolongamento de Três Corações e o ramal de Campanha foram explorados por concessão federal. "O primeiro não gozava de garantias de juros e o segundo tinha $5 \%$ durante a construção e 4\% após o término, sob o capital de 2.509:500\$000" (Lima, 1982, p. 103 apud Silva, 2012, p. 133). A inauguração da ferrovia se deu no ano de 1892 (no Prolongamento de Três Corações; em Campanha ocorreu em 1894), porém, já em 1908, foi incorporada à Minas e Rio, num processo que, futuramente, resultaria na formação da Rede Sul Mineira (Silva, 2012, p. 133). O quadro 1 mostra as estações da Companhia Estrada de Ferro Muzambinho.

Segundo Lima (apud Silva, 2012, p. 134), a Estrada de Ferro Muzambinho teve apenas dois presidentes: Carlos Augusto Miranda Jordão e Egas Muniz Barreto de Aragão. Carlos Augusto Miranda Jordão era do Rio de Janeiro, comissário de café com seu pai numa firma da família. "Foi ainda proprietário da Companhia Metropolitana de imigração, que a partir de 1890 administrou a colônia de italianos Nova Veneza, interior de Santa Catarina" (Silva, 2012, p. 134). Em 1892, possuía 16\% das ações da Companhia, sendo o maior acionista (Costa, 1966 apud Silva, 2012, p. 134).

14 Para as estradas de ferro Minas e Rio e Sapucaí, o movimento de exportações era maior que o de importações. Isso mostra nova dinâmica do sul-mineiro, em que a região passava a se dedicar também às atividades de exportação, e não apenas às de abastecimento e produção para o mercado interno. 
Quadro 1. Estações da Companhia Estrada de Ferro Muzambinho

\begin{tabular}{|c|c|c|c|}
\hline $\begin{array}{c}\text { Estação segundo Vasco de } \\
\text { Castro Lima } \\
(1934)\end{array}$ & $\begin{array}{l}\text { Localização no Álbum Chorographico } \\
\text { (1927) }\end{array}$ & Localização e situação atual & Data de inauguração \\
\hline Flora & Estação do município de Três Corações & $\begin{array}{l}\text { Estação demolida. Município } \\
\text { de Três Corações }\end{array}$ & 1896 \\
\hline Varginha & $\begin{array}{l}\text { Estação na sede do município } \\
\text { de Varginha }\end{array}$ & $\begin{array}{l}\text { Restaurada. Município de } \\
\text { Varginha }\end{array}$ & 1892 \\
\hline $\begin{array}{l}\text { Batista de Melo (ao inaugu- } \\
\text { rar-se chamava-se "Fluvial"). } \\
\text { Foi também chamada de } \\
\text { Esaú }\end{array}$ & $\begin{array}{l}\text { Estação Batista de Melo no município } \\
\text { de Varginha na margem direita do rio } \\
\text { Verde. Fluvial aparece como povoado na } \\
\text { margem esquerda do mesmo rio, já no } \\
\text { município de Eloy Mendes }\end{array}$ & $\begin{array}{l}\text { Inundada pela represa de } \\
\text { Furnas }\end{array}$ & 1893 \\
\hline Espera & Estação do município de Três Pontas & $\begin{array}{l}\text { Inundada pela represa de } \\
\text { Furnas (1960) }\end{array}$ & 1895 \\
\hline $\begin{array}{l}\text { Pontalete (ao inaugurar-se } \\
\text { chama-se "Pontal") }\end{array}$ & $\begin{array}{l}\text { Sede do distrito de Martinho Campos no } \\
\text { município de Três Pontas }\end{array}$ & $\begin{array}{l}\text { Inundada pela represa de } \\
\text { Furnas (1960) }\end{array}$ & 1895 \\
\hline Josino de Brito & Estação no município de Campos Gerais & $\begin{array}{l}\text { Inundada pela represa de } \\
\text { Furnas (1960) }\end{array}$ & 1909 \\
\hline Fama & $\begin{array}{c}\text { Estação na sede do distrito de Fama, } \\
\text { município de Alfenas }\end{array}$ & $\begin{array}{l}\text { Inundada pela represa de } \\
\text { Furnas (1960) }\end{array}$ & 1896 \\
\hline Gaspar Lopes & Estação do município de Alfenas & Estação Demolida & 1897 \\
\hline Harmonia & Estação no município de Alfenas & Sem dados sobre a estação & 1897 \\
\hline Areado & Estação no município de Areado & $\begin{array}{l}\text { Inundada pela represa de } \\
\text { Furnas (1960) }\end{array}$ & 1897 \\
\hline Movimento & Estação no município de Areado & Estação Demolida & 1908 \\
\hline Engenheiro Trompowsky & $\begin{array}{l}\text { Estação no distrito de São Joaquim da } \\
\text { Serra Negra do município de Alfenas }\end{array}$ & $\begin{array}{l}\text { Estação desativada situada na } \\
\text { Usina Monte Alegre. São Joa- } \\
\text { quim da Serra Negra hoje é o } \\
\text { município de Alterosa }\end{array}$ & 1909 \\
\hline $\begin{array}{l}\text { Tuiuti (ao inaugurar-se cha- } \\
\text { mava-se "Monte Belo") }\end{array}$ & $\begin{array}{l}\text { Tuiuty era estação do distrito de Monte } \\
\text { Belo do município de Muzambinho }\end{array}$ & $\begin{array}{l}\text { Município de Monte } \\
\text { Belo. Estação restaurada sem } \\
\text { vínculo com a fachada original }\end{array}$ & 1909 \\
\hline
\end{tabular}

Fonte: Costa, Costa e Lacerda (2015, p. 361).

Após a inauguração dos ramais, foi possível observar resultados bastante diferenciados entre eles: enquanto em Três Corações não se observou nenhum exercício com déficit, Campanha apresentou resultados negativos. Considerando o transporte de mercadorias e de passageiros, este último estava mais presente no ramal de Campanha em alguns anos; no caso do Prolongamento de Três Corações, o transporte de mercadorias sempre foi maior que o de passageiros (Silva, 2012, p. 134).

As estradas de ferro Sapucaí e Muzambinho corriam quase que paralelamente, ligando várias cidades sul-mineiras. A leste elas se ligavam à Minas e Rio e a oeste, se encontravam com a Mogiana.

A Estrada de Ferro Mogiana passava pelo Triângulo mineiro e pelo Sul de Minas, atingindo regiões de grande comércio de abastecimento, mas que também já começavam a produzir café para exportação. 
As estradas Muzambinho e Sapucaí eram subsidiárias da Companhia Minas e Rio, escoando seus produtos quase exclusivamente por ela. A configuração das mercadorias transportadas pela Companhia, na sua primeira década de operação, destaca as exportações de toucinho, fumo, queijos e café (este último começa a aparecer já no segundo ano de atuação da Companhia, 1885, como um dos principais itens). Gado e sal também eram transportados, consistindo o último num artigo de importação e responsável individualmente pelo maior percentual das mercadorias transportadas entre 1884 e 1888, em quantidade por quilos, sendo o que mais gerava receitas. O item "diversos" também era destaque no transporte de mercadorias, sendo compreendidos nele açúcar, alcoólicos, água mineral e cereais, dentre os principais produtos (Silva, 2012, cap. 3).

A partir dessas observações, pode-se inferir que o café não era o principal produto transportado durante todo o tempo de atuação das ferrovias, mas sua ascensão merece destaque: em 1884, o café não aparecia dentre os itens transportados pela Minas e Rio. A partir de 1885, aparece em pequenas quantidades, mas ainda sem gerar receitas. Em 1888, a receita do café não chegava a 50 contos de réis. Entretanto, após 1893, o transporte de café começa a expandirse.

Entre o período de 1893 e 1897, por exemplo, a Estrada Minas e Rio transportava café, sal, toucinho, fumo, queijos, cereais, açúcar, animais e alcoólicos. Naquele ano, as receitas com café chegaram a 100 contos de réis e, no ano de 1897 o café transformou-se no principal produto de exportação da ferrovia, chegando as receitas oriundas da mercadoria a 500 contos de réis. No ano de 1901, as receitas com o produto chegaram a 800 contos de réis. E em 1903 e 1907, as receitas com café chegaram, respectivamente, a 500 e 600 contos de réis (Silva, 2012a, pp. 199-201). O transporte de café deslocou das posições iniciais os produtos que já eram exportados. Verifica-se, portanto, a predominância de produtos agropecuários destinados ao mercado interno para os primeiros anos de operação da Companhia Minas e Rio, e também a relevância do café a partir dos últimos anos do século XIX, como produto de exportação.

A tabela 1 mostra as tarifas cobradas pelas estradas de ferro Sapucaí, Minas e Rio e Muzambinho (contemplando também a Oeste de Minas).

Considerando as tarifas cobradas pelas estradas de ferro (Sapucaí, Minas e Rio e Muzambinho), é possível frisar (para o ano de 1906), a relevância para o café e o fumo, nos casos das três ferrovias. Os itens relacionados à pecuária (porcos, ovelhas e cabritos; bois, cavalos e muares) eram os que demandavam as menores tarifas. Inclusive no caso da Oeste de Minas, as tarifas cobradas da categoria de fumo e café possuíam maior destaque.

Por meio do exemplo da cobrança destas tarifas do ano de 1906, pode-se pensar numa relevância do café para a economia do Sul de Minas Gerais. Agricultura que, aos poucos, contribuía para uma transformação da região como um todo.

A característica de variedade produtiva do Sul de Minas Gerais, prevalecente na região desde os tempos coloniais, quando esta servia, sobretudo ao abastecimento do Rio de Janeiro, se manteve após a chegada das ferrovias, embora o café passasse a ocupar as primeiras posições no decorrer do tempo, fazendo com que a região avançasse no comércio de exportação. 
Tabela 1. Comparação de tarifas entre as ferrovias Sapucaí, Minas e Rio, Muzambinho e Oeste de Minas (1906) por tonelada/quilômetro

\begin{tabular}{|c|c|c|c|c|}
\hline Item & $\begin{array}{l}\text { Sapucaí } \\
\text { (400 kms) }\end{array}$ & $\begin{array}{l}\text { Minas e Rio } \\
(170 \mathrm{kms})\end{array}$ & $\begin{array}{l}\text { Muzambinho } \\
(238 \mathrm{kms})\end{array}$ & $\begin{array}{l}\text { Oeste de Minas } \\
\qquad(944 \mathrm{kms})\end{array}$ \\
\hline $\begin{array}{l}\text { Queijose } \\
\text { manteiga }\end{array}$ & $\begin{array}{c}\$ 090 \text { até } 150 \text { kms } \\
\$ 060 \text { de } 150 \text { em diante }\end{array}$ & $\$ 250$ & $\$ 188$ & $\begin{array}{c}\$ 200 \text { até } 100 \text { kms } \\
\$ 100 \text { de } 101 \text { a } 300 \text { kms } \\
050 \$ \text { de } 301 \text { em diante }\end{array}$ \\
\hline Café e fumo & $\begin{array}{c}\$ 330 \text { até } 150 \mathrm{kms} \\
\$ 200 \text { de } 150 \text { em diante }\end{array}$ & $\begin{array}{l}\$ 287,5 \text { até } 150 \mathrm{kms} \\
\begin{array}{c}\$ 264,5 \text { de } 150 \mathrm{em} \\
\text { diante }\end{array}\end{array}$ & $\$ 310$ & $\begin{array}{c}\$ 300 \text { até } 100 \text { kms } \\
\$ 200 \text { de } 101 \text { a } 300 \text { kms } \\
100 \$ \text { de } 301 \text { em diante }\end{array}$ \\
\hline $\begin{array}{l}\text { Cereais e } \\
\text { batatas }\end{array}$ & $\$ 200$ por saco de $62,5 \mathrm{~kg}$ & $\begin{array}{c}\$ 030 \text { até } 100 \mathrm{kms} \\
\$ 020 \text { de } 100 \mathrm{em} \\
\text { diante }\end{array}$ & $\$ 100$ & $\begin{array}{c}\$ 100 \text { até } 100 \text { kms } \\
\$ 50 \text { de } 101 \text { a } 300 \text { kms } \\
\$ 025 \text { de } 301 \text { em diante }\end{array}$ \\
\hline Água mineral & $\begin{array}{c}\$ 050 \text { até } 150 \mathrm{kms} \\
\$ 040 \text { de } 150 \text { em diante }\end{array}$ & $\$ 100$ & $\$ 100$ & $\begin{array}{c}\$ 100 \text { até } 100 \text { kms } \\
\$ 070 \text { de } 101 \text { a } 300 \text { kms } \\
\$ 050 \text { de } 301 \text { em diante }\end{array}$ \\
\hline Sal & $\$ 060$ & $\$ 150$ & $\$ 150$ & $\begin{array}{c}\$ 200 \text { até } 100 \text { kms } \\
\$ 100 \text { de } 101 \text { a } 300 \text { kms } \\
\$ 050 \text { de } 301 \text { em diante }\end{array}$ \\
\hline Açúcar & $\$ 140$ & $\$ 250$ & $\$ 100$ & $\begin{array}{c}\$ 200 \text { até } 100 \text { kms } \\
\$ 100 \text { de } 101 \text { a } 300 \text { kms } \\
\$ 050 \text { de } 301 \text { em diante }\end{array}$ \\
\hline $\begin{array}{l}\text { Porcos, ove- } \\
\text { Ihas e cabritos }\end{array}$ & $\$ 018$ até $150 \mathrm{kms}$ & $\$ 015$ & $\$ 015$ & $\$ 045$ \\
\hline $\begin{array}{c}\text { Bois, cavalos e } \\
\text { muares }\end{array}$ & $\$ 055$ & $\$ 055$ & $\$ 055$ & $\$ 045$ \\
\hline
\end{tabular}

Fonte: Lima (1934) apud Silva (2012, p. 203).

Em fins do século $\mathrm{XIX}^{15}$ mais precisamente antes de meados da década de 1880 , a Zona da Mata foi a localidade de Minas Gerais que registrou a maior quantidade de ramais ferroviários, porém, com o passar do tempo, a expansão das linhas praticamente estabilizou-se naquela região. E dessa forma, "entre 1890 e 1906, a rede Sulista cresceu de 246 para 923 quilômetros, enquanto na Mata a Leopoldina acrescentou apenas 86 quilômetros à linha de Muriaé" (Blasenhein, 1996, p. 108). Proporcionalmente, "desde 1884 a rede da Mata tinha diminuído de dois terços para um quarto do total mineiro" (Blasenhein, 1996, p. 108). Pode ser observado, então, um considerável aumento da malha ferroviária sul-mineira na passagem de um século ao outro e, juntamente com a chegada das ferrovias, intensificação do comércio do Sul mineiro.

É possível dizer que as estradas que avançaram pelo Sul de Minas Gerais na passagem do século XIX para o século xx foram atraídas por fatores correlacionados: o processo de urbanização em curso; a chegada da atividade da cafeicultura na região; as possibilidades de auferirem-se lucros oriundos das transformações urbanas e econômicas às quais o sul de Minas

15 Sobre particularidades do transporte ferroviário mineiro no século XIX, conferir Godoy e Barbosa (2008).

tiempo\&economía

Vol. 5 N. ${ }^{\circ} 2$ - Julio - Diciembre del 2018 
passava, com o processo de urbanização e o desenvolvimento da cafeicultura. E em meio as transformações do Sul mineiro, as ferrovias, atraídas para a região, passaram também a fazer parte daquele conjunto de novos elementos que contribuíram com a formação do capitalismo sul-mineiro. As cidades da região passavam por um crescimento particular, limitado, de localidades do interior do Brasil, mas que jamais deve ser esquecido.

Com o passar do tempo, a configuração das estradas de ferro que percorriam o Sul de Minas Gerais se alterou, em comparação àquela vista em 1890, por meio do mapa 2 apresentado acima neste texto. Assim, o mapa 3 abaixo mostra a localização das ferrovias no Sul de Minas em 1920.

Mapa 3. Localização das ferrovias no Sul de Minas Gerais, 1920

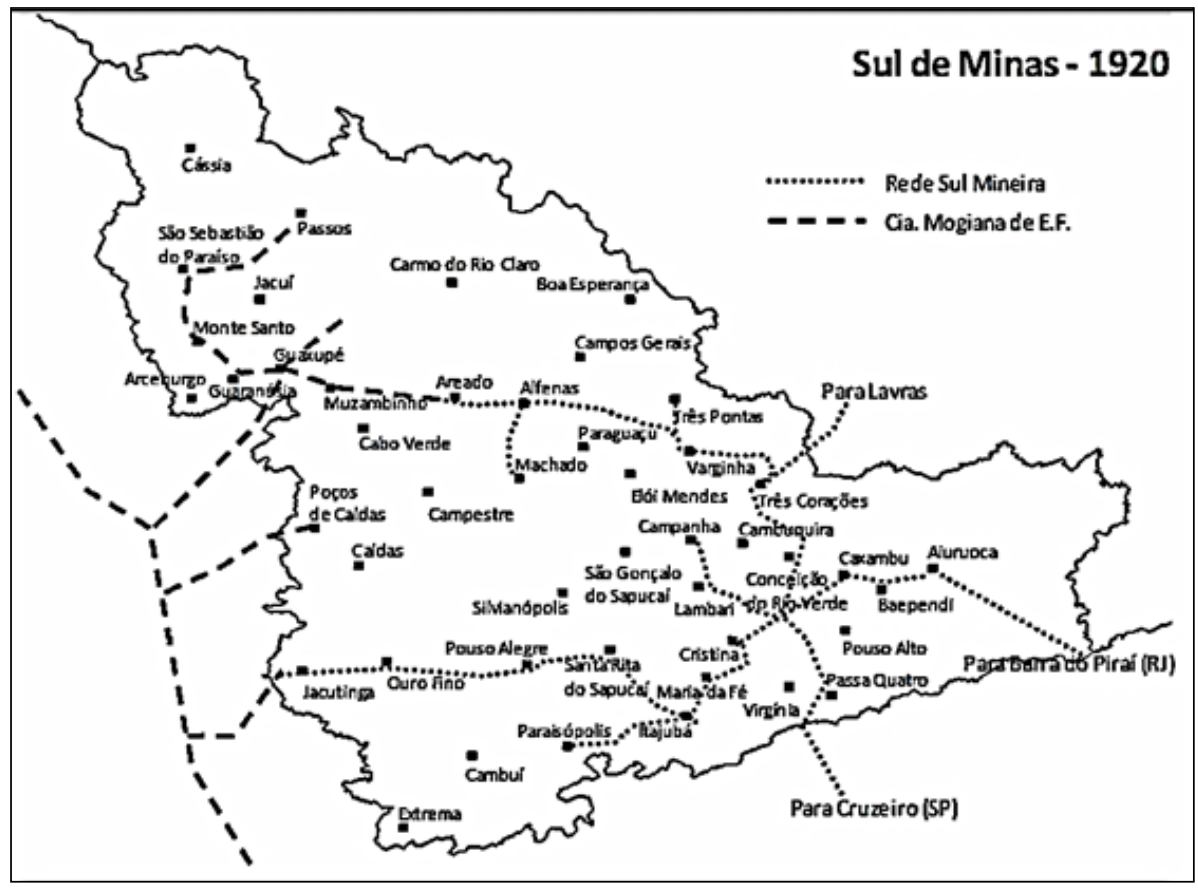

Fonte: Saes, Gambi e Curi (2016, p. 39)

Por meio do mapa 3 é possível notar não apenas o aumento de ramais locais, mas a ampliação do número de municípios, em comparação com o mapa 2. O Sul de Minas Gerais passava por nova movimentação urbana, econômica e social. A introdução e importância do café na região, juntamente com o aumento populacional e a chegada das estradas de ferro, davam nova forma ao Sul de Minas Gerais. Em meio às transformações do Sul mineiro, Varginha passou pela emancipação no final do século XIX.

\section{O município de Varginha: as principais atividades econômicas}

Foi "Aos dezecete dias do mez de dezembro de mil oitocentos e oitenta e dois... no Paço da Camara Municipal desta Villa" que ocorreu a primeira reunião da Câmara de vereadores de Var- 
ginha (ACMv, 1882, p. 1). ${ }^{16}$ Até aquela data, o antigo distrito pertencia à municipalidade de Três Pontas. Naquela primeira reunião, foi escolhido o primeiro presidente da Câmara Municipal, major Matheus Tavares da Silva ${ }^{17}$, sendo o vice presidente, José Maximiano Baptista. ${ }^{18}$

A primeira reunião da Câmara Municipal de Varginha ocorreu ao final do ano de 1882, contudo, claramente, num período bem anterior ao do fim do século xIX, as terras que abrigariam o município já eram povoadas.

Anos antes de 1806, o casal Francisco Alves da Silva e Tereza Clara Rosa da Silva adquiriu as terras onde mais tarde se localizaria Varginha. $\mathrm{O}$ casal vendeu essas terras ao alferes Manoel Francisco de Oliveira no ano de 1806 e, posteriormente, elas foram doadas à diocese de Campanha (Sales, 2003).

Affonso Ávila afirmou que o povoado surgiu em fins do século xVIII, por volta de 1785 , e se encontrava no meio do caminho que ligava a Vila de Campanha ao Sertão de Três Pontas. A exemplo da tradição observada em grande parte dos povoados mineiros, surgidos no século XIX, à área inicial de Varginha compreendia cerca de 48 alqueires (Ávila, 1983, p. 2).

Entre 1785 e 1820 foram construídas no local cerca de seis casas de telhas. No ano de 1824, o arraial contava com cerca de 1.550 habitantes, distribuídos pelas fazendas já formadas ou ainda em formação (Ávila, 1983, p. 8). Pela Lei 471, de 1 de junho de 1850, o antigo curato do Espírito Santo da Varginha transformou-se em freguesia, sendo subordinado ao município de Três Pontas (Veiga, 1884, p. 182).

Com o passar dos anos, o espaço onde se localizaria Varginha somava elementos importantes para a sua formação e para a evolução de seu processo de urbanização. Assim, o número de habitantes aumentava, embora de forma gradual, como mostra a tabela 2.

Mas -e o que parece comum na formação inicial da maioria das cidades não planejadas, que crescem naturalmente- apesar de um primitivo processo de urbanização em curso, as pessoas se concentravam, sobretudo, no campo, durante muitos anos. Se formava, entretanto, uma economia urbana, de forma que o espaço rural não viveria isolado do urbano, e este passava a influenciar o campo. ${ }^{19}$ Juntamente àquele movimento, a economia do município se fortalecia. ${ }^{20}$

Dentre as principais atividades econômicas, destacava-se a da cafeicultura. De acordo com José Lefort, o café foi introduzido em Varginha por volta de 1870, apenas para o consumo de seus plantadores, sem ainda ser comercializado (Lefort, 1950 apud Sales, 2003). Mas a cultura

16 Vale ressaltar que o município de Varginha era formado pela cidade de Varginha mais os distritos de Pontal e Carmo da Cachoeira, emancipados, respectivamente, em 1911 e 1938.

17 Descrito no Almanach Sul-Mineiro para 1884 (pp. 187-189) como capitalista, negociante, fazendeiro com engenho movido à água, tropeiro e açougueiro. Contribuiu financeiramente para que a ferrovia passasse por Varginha. Dentre os moradores do município na passagem para o século XX, foi um dos membros que mais posses detinha. Faleceu em 1905 deixando dois filhos. Mais informações sobre o major podem ser encontradas em seu processo de inventário post-mortem, presente no Arquivo do Judiciário da Comarca de Varginha: ano 1905, caixa 598, documento 23.

18 Descrito no Almanach Sul-Mineiro para 1884 (p. 187) como proprietário de estabelecimento de secos e molhados.

19 A influência entre os espaços rural e urbano se dá, por exemplo, no suprimento de alimentos que o campo fornece à cidade; e nos serviços que a cidade oferece ao campo.

20 Foi a partir de 1940 que passou a ocorrer maior concentração de pessoas na área urbana de Varginha.

tiempo\&economía

Vol. 5 N. ${ }^{\circ} 2$ - Julio - Diciembre del 2018

p. 71

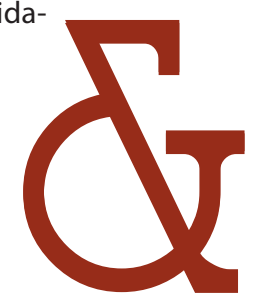


desenvolveu-se, dentro dos limites estruturais varginhenses, de forma satisfatória. Já em 1893, afirmou Rubião, foi inaugurada no município a primeira máquina de beneficiar café (Rubião, 1919 apud Sales, 2003). Em 1920 eram 113 estabelecimentos de beneficiar o produto, "tendo eles produzido 23.916 quintais, nos seus 4.394.000 pés de café" (Lefort, 1950 apud Sales, 2003, p. 285).

Tabela 2. Número de habitantes do município de Varginha, 1890-1920

\begin{tabular}{|c|c|}
\hline Ano & População \\
\hline 1890 & 24.819 \\
\hline 1900 & 29.322 \\
\hline 1907 & 31.417 \\
\hline 1908 & 31.728 \\
\hline 1909 & 32.042 \\
\hline 1910 & 32.359 \\
\hline 1911 & 32.690 \\
\hline 1912 & $20.690^{*}$ \\
\hline 1913 & 21.029 \\
\hline 1914 & 21.237 \\
\hline 1915 & 21.447 \\
\hline 1916 & 21.659 \\
\hline 1917 & 21.874 \\
\hline 1918 & 22.080 \\
\hline 1919 & 22.309 \\
\hline 1920 & 22.457 \\
\hline
\end{tabular}

A área central da cidade apresentava primitivas casas comerciais e de serviços, encontrando-se, dentre outros: farmácias, consultórios médicos, comércios de venda por atacado e varejo, alfaiatarias, pensões, oficinas de sapateiros, selarias, dentistas, açougues, relojoarias e depósitos de mobílias (Sales, 2003, pp. 280-281).

A movimentação que a cafeicultura e o comércio levaram até o município ocorreu com auxílio de uma inovação para a época e para a sociedade varginhense: a estrada de ferro. No dia 28 de maio de 1892, a estação férrea Muzambinho, partindo de Três Corações (município próximo), foi inaugurada (Sales, 2003, p. 180). É possível observar o caminho percorrido pela estrada no mapa 4.

Com a estrada de ferro passando por Varginha, a atividade do comércio e as exportações, especialmente de café, passaram a se expandir, já que mercadorias poderiam ser enviadas a outras cidades, não apenas do Sul de Minas, mas de outras localidades de Minas Gerais.

Em 1913, por exemplo, a cidade de Varginha exportava uma média anual de 400 mil arrobas de café (Questionários sobre as condições da agricultura de 176 municípios no Estado de Mi-

* Até 1911, o município de Varginha era formado pelas populações da cidade e de seus dois distritos. Após aquele ano, Pontal foi emancipada, dando origem à cidade de Elói Mendes. 
nas Geraes, 1913, p. 505); em 1918, a média de exportações de café que passava pela estação local da Estrada de Ferro Muzambinho chegou a atingir 200 mil sacas, sendo 125 mil dessas sacas produzidas em Varginha -mas que incluía a produção de Carmo da Cachoeira, distrito que ainda não havia se emancipado. As 75 mil sacas restantes eram de outros municípios vizinhos (Ávila, 1983, p. 14).

Mapa 4. O caminho percorrido pela Estrada de Ferro Muzambinho no Sul de Minas Gerais

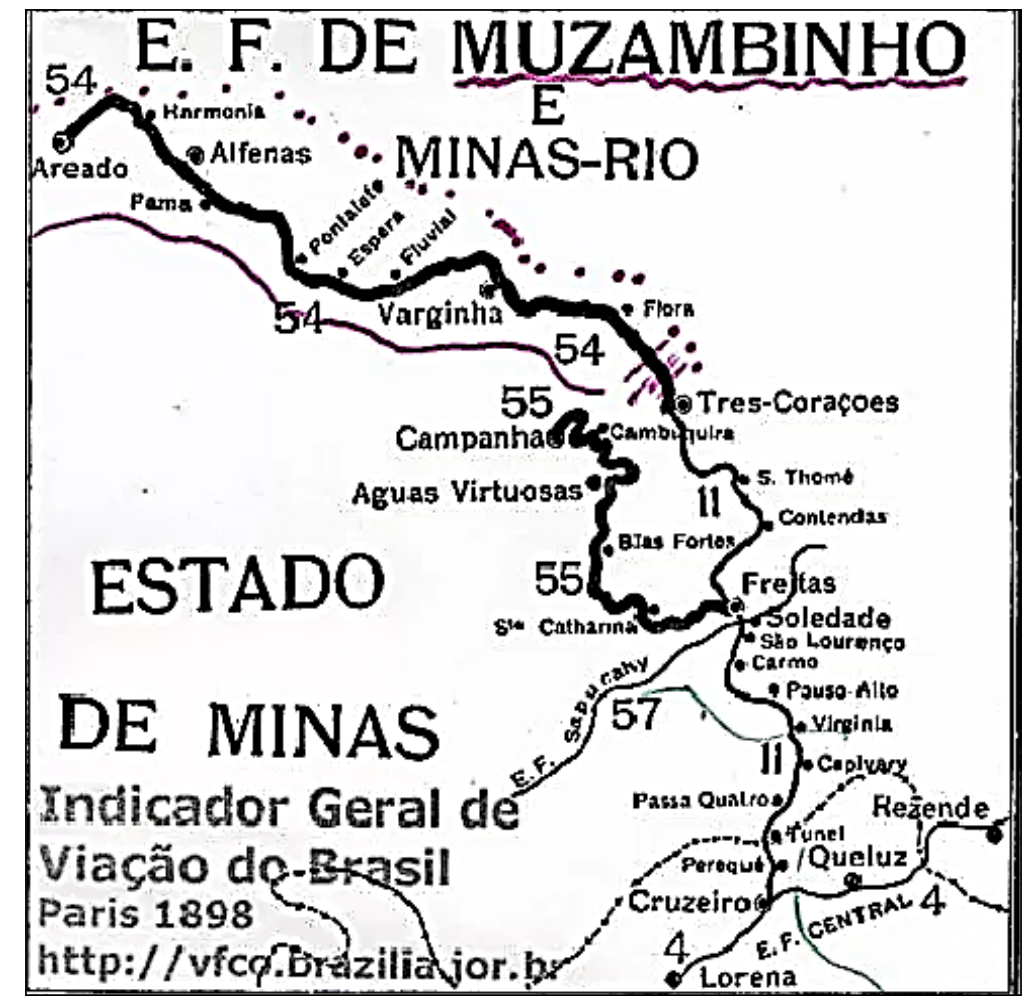

Fonte: http://www.blogdomadeira.com.br/2012/05/120-anos-da-ferrovia-em-varginha/ Acesso em: 10/03/2018

E em meio às transformações urbanas às quais passava a cidade, as instituições bancárias chegaram na quarta década de sua formação, depois que o espaço urbano se desenvolvia de forma gradual. Em 1915, foi inaugurada uma agência do Banco Hypotecário e Agrícola do Estado de Minas Geraes e, antes disso, em 1912, havia sido inaugurada uma agência do Banco do Brasil. As duas agências "luxuosamente instaladas em prédios próprios", facilitavam a circulação monetária na cidade (Fonseca e Liberal, 1920 apud Sales, 2003, p. 281). Claramente, as instituições realizavam apenas operações mais simples, como depósitos.

Naquele contexto de formação de cidade, as primeiras fábricas que surgiram contaram com bases ainda primitivas, se comparadas às indústrias, por exemplo, de cidades da Zona da Mata mineira, como Juiz de Fora, no mesmo período em que se analisa Varginha. ${ }^{21}$

21 Sobre a economia de Juiz de Fora na transição para o século XX, ver: Pires, 2009.

tiempo\&economía

Vol. 5 N. ${ }^{\circ} 2$ - Julio - Diciembre del 2018 
Foi em 1893 que surgiu o primeiro estabelecimento que remetia a uma indústria: a fábrica de vinhos produzia cinco pipas anualmente, sendo $300 \$ 000$ (trezentos mil réis) cada uma. As cinco pipas produzidas por ano correspondiam a 2.486 .000 litros de vinho, que eram consumidos localmente (Sales, 2003, pp. 279-280). Em 1893 Varginha também contava com uma fábrica de meias de lã. ${ }^{22}$

O café, que era um dos principais produtos de exportação do município, estava vinculado à indústria. "Entre os principais estabelecimentos industriais, destacam-se os destinados ao beneficiamento e rebeneficiamento do café, todos localizados em proximidade da estação férrea de Varginha" (Rubião, 1919 apud Sales, 2003, pp. 279-280).

Em relação às demais fábricas (além das fábricas de vinho e de meias de lã, e dos estabelecimentos de beneficiar café), Fonseca e Liberal (1920) afirmaram que existiam as de: aguardente, rapadura, manteiga, balas, caramelos e bebidas; as máquinas de aluguel de beneficiar arroz, as oficinas de ferreiros, as padarias e uma fábrica de banhas (apud Sales, 2003, pp. 280281).

Tem-se, portanto, um panorama geral da formação econômica de Varginha na passagem do século xIx para o século $x x$, com destaque para suas principais atividades econômicas, que se diferenciavam de economias de algumas cidades do Sul de Minas Gerais: a economia de Alfenas, por exemplo, era baseada principalmente na atividade agropecuária (Martins e Souza, 2012). No caso de Lavras, em fins do século XIX, destacavam-se as atividades de produção de gêneros agrícolas para abastecimento de regiões produtoras de café e criação de animais (Vieira, 2015, pp. 114-115).

A economia varginhense tinha como uma de suas principais atividades a cafeicultura, que teve como se expandir graças ao serviço da ferrovia que, em fins do século XIX, chegou ao município.

A título de comparação, a tabela 3 mostra a população de Varginha e alguns dos municípios sul-mineiros, do período de 1873 até 1910. Por meio da tabela, é possível pensar sobre a relação do crescimento populacional de tais municípios e a chegada da estrada de ferro.

Campanha (chegada da ferrovia em 1897), a principal cidade do Sul de Minas Gerais no século XIX, passou por decrescimento populacional ao longo do tempo, mesmo contanto com um ramal da ferrovia Muzambinho ainda antes da virada para o século xx. Municípios que se emanciparam antes de Varginha, como Passos (chegada da ferrovia em 1921) e Pouso Alegre (chegada da ferrovia em 1895), passaram também por decrescimento populacional. Alfenas (chegada da ferrovia em 1897) passou pela emancipação anteriormente à emancipação varginhense, e sua população cresceu pouco entre o período descrito pela tabela.

A estação ferroviária da Companhia Estrada de Ferro Muzambinho foi inaugurada em Varginha em 1892 e pode-se observar que a população do município passou por importante crescimento populacional a partir da década de inauguração. Pouso Alto (chegada da ferrovia em

22 No período de 1882 até 1920, os registros de imóveis do município de Varginha mostraram transações envolvendo algumas empresas. Eram elas: Arbichkes Companhia; Caldas Bastos e Cia; Azevedo Silva e Cia; Smith Thompson Bryan; Hand, Rand e Cia; e, Arbnakle Brothers (Registros de Imóveis do município de Varginha, depositados no Cartório de Registros de Imóveis da cidade). 
1884) e Três Corações (chegada da ferrovia em 1884) também passaram por crescimento populacional, de certa forma, relevante ao longo do período em que mostra a tabela.

Tabela 3. População de Varginha e demais municípios sul-mineiros ${ }^{23}$

\begin{tabular}{|c|c|c|c|c|c|}
\hline Município & 1873 & 1890 & 1907 & 1910 & Ferrovia em \\
\hline Alfenas & 28.181 & 25.434 & 29.282 & 31.265 & 1897 \\
\hline Baependi & 22.619 & 35.879 & 30.823 & 32.345 & 1895 \\
\hline Campanha & 33.720 & 16.185 & 8.231 & 8.607 & 1895 \\
\hline Cristina & 24.412 & 13.120 & 12.132 & 12.686 & 1891 \\
\hline Guaxupé & 4.415 & 6.453 & - & $19.671 *$ & 1904 \\
\hline Itajubá & 17.870 & 40.900 & 30.432 & 31.094 & 1891 \\
\hline Lavras & 26.400 & 36.810 & 71.456 & 74.721 & 1895 \\
\hline Ouro Fino & 9.197 & 23.634 & 36.877 & 40.201 & 1896 \\
\hline Passos & 23.369 & 19.179 & 12.157 & 12.780 & 1921 \\
\hline Poços de Caldas & - & 1.830 & 9.145 & 9.563 & 1886 \\
\hline Pouso Alegre & 41.115 & 37.422 & 35.363 & 36.978 & 1895 \\
\hline Pouso Alto & 14.811 & 26.321 & 32.964 & 34.210 & 1884 \\
\hline Três Corações & 3.154 & 6.214 & 11.736 & 13.606 & 1884 \\
\hline Varginha & 7.195 & 24.819 & 31.967 & 33.427 & 1892 \\
\hline
\end{tabular}

Fonte: Silva (2012, p. 202). ${ }^{*}$ Dados para 1913.

Por meio dos dados da tabela, é possível dizer que a chegada da ferrovia contribuiu para o aumento da população dos municípios por onde passou, e que esse movimento de aumento populacional depende também de um contexto econômico mais geral. No caso de Varginha, que se emancipou depois de muitos municípios sul-mineiros (num contexto de transformações sociais, econômicas e urbanas no Brasil), a chegada da ferrovia, mesmo depois da inauguração do serviço em demais municípios descritos pela tabela 3, além de contribuir para o avanço do crescimento populacional, auxiliou na promoção de crescimento econômico e urbano.

23 Considerando os dados populacionais do município de Varginha em alguns períodos, o número da população difere sensivelmente do apresentado na tabela 2. Isso ocorre, provavelmente, devido à fonte primária utilizada para a elaboração das tabelas, e não prejudica as análises realizadas neste texto. 


\section{A chegada da estrada de ferro em Varginha: transformações econômicas e urbanas}

Foi no dia 28 de maio de 1892 que se inaugurou a estação férrea Muzambinho em Varginha, partindo de Três Corações. Fonseca e Liberal referiram-se ao serviço como uma importante alavanca para o progresso da cidade. Segundo os autores, "a chegada da linha férrea formou em sólidos alicerces a base de nossa prosperidade" (apud Sales, 2003, p. 180). Ainda de acordo com os autores:

a ferro-via Muzambinho, que timbrou, em todo o seu trajeto, em margear o Rio Verde, deixando de lado as cidades vizinhas, como Três Pontas e Alfenas, esta ultimamente beneficiada por um ramal especial, desviando-se do leito desse rio, no Porto Farinhas, resolveu galgar alguns outeiros e cortar essa cidade [Varginha] em toda a sua extensão (Fonseca e Liberal, 1920 apud Sales, 2003, p. 180, grifos dos autores).

Pela ata da Câmara Municipal de 10 de dezembro de 1891 é possível perceber a movimentação na cidade por conta das obras da estação ferroviária.

Deliberou o Conselho que: attendendo a falta de trabalhadores hoje existentes nesta cidade, em rasão das muitas obras em andamento, provenientes em sua maior parte da abertura de diversos quintaes para passagem de ferro-via Muzambinho, e bem assim as edificações particulares, que fossem relevadas multas em que incorrerão todos os proprietarios que deixarão de fechar seus quintaes com muros (ACMV, 1891, p. 40).

Nenhum registro posterior àquela data, referente à passagem da ferrovia, foi encontrado nas atas da Câmara. No entanto, a passagem citada acima chama atenção, sobretudo, na parte em que diz: "em rasão das muitas obras em andamento, provenientes em sua maior parte da abertura de diversos quintaes para a passagem da ferro-via Muzambinho". É possível entender que, juntamente com as obras da ferrovia, se desenvolviam demais obras no perímetro urbano de Varginha, significando crescimento urbano.

Se as atas da Câmara mostraram que, no mês de dezembro de 1891, alguns terrenos foram abertos para as obras da ferrovia, por meio dos registros de imóveis, ${ }^{24}$ é possível confirmar o acontecimento: a Companhia Estrada de Ferro Muzambinho desapropriou onze moradores de seus terrenos, como pode ser conferido por meio da tabela 4.

O título de todas as propriedades era indenização por desapropriação, e o valor de muitas das indenizações é considerado baixo, se comparado com o preço das casas vendidas no espaço urbano e com os preços das propriedades rurais.

A Companhia Muzambinho registrou a compra de mais dois imóveis rurais, nos anos de 1892 e 1895. Em 1892, foi adquirido um terreno cujo registro continha nas características: terreno para estrada de ferro Muzambinho, para a estação fluvial no Rio Verde, ferrovia com 9 metros para cada lado e estação de 1.000 metros de comprimento. O título era compra e venda, sendo a escritura pública. O valor da compra foi de aproximadamente $800 \$ 000$ (oitocentos mil réis).

24 Para pesquisa que utilizou de registros de imóveis, conferir: Marcondes e Oliveira (2013). 
Tabela 4. Terrenos adquiridos pela Companhia Estrada de Ferro Muzambinho, 1891

\begin{tabular}{|c|c|c|c|c|c|}
\hline Data & $\begin{array}{l}\text { Freguesia do } \\
\text { imóvel } \\
\text { Imóvel }\end{array}$ & Denominação & Tipo & Características & Valor em mil réis \\
\hline 11/12/1891 & \multirow{11}{*}{ Varginha } & \multirow{10}{*}{ Terreno e prédio } & \multirow{11}{*}{ Urbana } & \multirow{11}{*}{$\begin{array}{l}\text { Terreno para estrada de } \\
\text { ferro Muzambinho }\end{array}$} & $400 \$ 000$ \\
\hline 11/12/1891 & & & & & $400 \$ 000$ \\
\hline 12/12/1891 & & & & & 1:100\$000 \\
\hline 12/12/1891 & & & & & $400 \$ 000$ \\
\hline 14/12/1891 & & & & & $400 \$ 000$ \\
\hline 14/12/1891 & & & & & $50 \$ 000$ \\
\hline 15/12/1891 & & & & & $100 \$ 000$ \\
\hline 15/12/1891 & & & & & $200 \$ 000$ \\
\hline 16/12/1891 & & & & & $50 \$ 000$ \\
\hline 16/12/1891 & & & & & $80 \$ 000$ \\
\hline 17/12/1891 & & Terreno & & & $80 \$ 000$ \\
\hline
\end{tabular}

Fonte: elaboração própria a partir dos Registros de Imóveis do ano de 1891, presentes no Cartório de Registros de Imóveis de Varginha.

No registro de 1895 estava escrito nas características: terreno da fazenda para estação fluvial e suas dependências com 300 metros de comprimento. No título constava acordo, sendo a escritura pública. A compra custou aproximadamente $750 \$ 000$ (setecentos e cinquenta mil réis). ${ }^{25}$ Os dois imóveis foram adquiridos do mesmo proprietário, o senhor Esaú José Nogueira que, em 1892, residia em Três Corações e, em 1895, em Varginha.

Segundo Sales (2003), o projeto original da Estrada de Ferro Muzambinho não contava com uma estação em Varginha. O projeto inicial previa que a ferrovia, margeando o Rio Verde, ligasse a cidade de Cruzeiro, em São Paulo, até Gaspar Lopes, cidade mineira situada próximo de Muzambinho. Como os terrenos em Varginha eram mais elevados que o nível do rio, os custos para que a estrada passasse pela cidade se elevariam. Assim, precisou-se de intervenção particular para que fosse construída a estação de Varginha. O auxílio financeiro partiu do major Matheus Tavares da Silva, o primeiro presidente da Câmara Municipal varginhense, que conversou pessoalmente com o engenheiro responsável pelas obras, em Varginha, e se dispôs a pagar o necessário para a construção de uma estação na cidade. ${ }^{26}$

Depois de três meses para novos estudos acerca da possibilidade da passagem da ferrovia por Varginha o projeto original foi reformulado e a ferrovia passou pela cidade, com acréscimo dos 100 contos de réis financiados por Matheus Tavares da Silva (Sales, 2003, pp. 182-184).

O major Matheus Tavares da Silva ocupou o cargo de presidente da Câmara de vereadores desde dezembro de 1882 (emancipação do município) até o final do ano de 1886, ou seja, o major conduziu o município na fase mais inicial de sua formação. O influente membro da

25 Para mais detalhes sobre o transporte fluvial no Sul de Minas Gerais, é possível recorrer a Martins (2011).

26 Matheus Tavares da Silva foi comerciante e negociante, produtor de café, possuía muitas extensões de terras: cerca de três mil alqueires, distribuídos entre Varginha, Três Pontas e Carmo da Cachoeira (Sales, 2003, p. 181).

tiempo\&economía

Vol. 5 N. 2 - Julio - Diciembre del 2018

p. 77

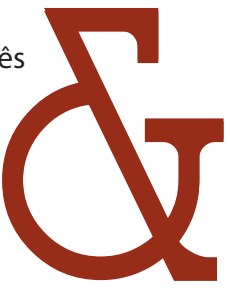


sociedade varginhense foi descrito no Almanach Sul-Mineiro para 1884 como capitalista, negociante, fazendeiro, tropeiro e açougueiro (Veiga, 1884, pp. 187-189). Em seu inventário ${ }^{27}$, havia uma passagem dizendo que "declarou mais o inventariante que o espólio possui uma cautela da Estrada Muzambinho". O valor da cautela era de 50:000\$000 (cinquenta contos de reis).

Como primeiro presidente da Câmara Municipal de Varginha e proprietário de uma das maiores riquezas da localidade no período de 1882 e 1920, o major Matheus Tavares da Silva contribui financeiramente para a construção da estação por dois motivos: primeiramente, por fazer parte da elite política do município, por ter ocupado um cargo importante na municipalidade, o major provavelmente agiu de forma a tentar levar para Varginha (com o financiamento de parte da construção da estação ferroviária) crescimento econômico e urbano.

Considerando o alto valor da riqueza de Matheus Tavares da Silva ${ }^{28}$, investir na estrada de ferro não foi problema. Além disso, para o major, a passagem da ferrovia por Varginha contribuía para a expansão de seus próprios interesses. Além de almejar o progresso da cidade, Matheus Tavares da Silva, como negociante, comerciante, fazendeiro e produtor de café, financiou quantia da estação da ferrovia porque o serviço seria necessário para a expansão de seus investimentos.

Sales escreveu que, sem dúvida, a passagem da ferrovia por Varginha contribuiu de forma muito relevante para o crescimento não apenas da cidade, mas também da região sul-mineira como um todo. Não obstante, o autor afirmou que a inovação não foi recebida com o devido entusiasmo pela imprensa. No dia 30 de maio de 1892, a coluna "Várias Notícias" do Minas Gerais, órgão oficial dos poderes do Estado, mencionou apenas a seguinte frase, de acordo com Sales: "Foi inaugurada a Estação da Varginha, da Companhia Muzambinho" (Sales, 2003, p. 180).

A figura 1 representa a chegada da estrada de ferro em Varginha, em maio do ano de 1892.

Ávila (1983, p. 14) escreveu que a tendência e vocação de Varginha para o comércio foi estabelecida já na época de sua caracterização como pequeno núcleo urbano. A princípio, o autor afirmou que essa tendência e vocação se cumpriam em relação quase apenas aos contingentes agrícolas do próprio município.

Mas Veiga (1874), em seu Almanach Sul-Mineiro para 1874, constatou que Varginha enviava para a corte alguns gêneros, tais como fumo e toucinho, porcos e gado vacum. E recebia de lá ferragens, louça, bebidas e sal, este último, em grande quantidade, comparado com os demais itens importados, chegando a mais de 3.000 sacas anualmente. Isso mostra, assim como ocorreu para o Sul de Minas como um todo, ao longo do século xIX, a relevância do comércio de abastecimento, que também estava presente em Varginha.

27 Dentre os inúmeros trabalhos que partiram de inventários post-mortem, ver Mello (1985), Lopes (2005) e Vieira (2015).

28 Matheus Tavares da Silva possuía uma riqueza de cerca de 440 contos de réis quando faleceu em 1905. Considerando o contexto sul-mineiro da passagem do século XIX para o século XX, era um valor considerável. Dentro do município de Varginha o major era um dos mais ricos moradores. 
Figura 1. Inauguração da estação da estrada de ferro Muzambinho em Varginha (1892)

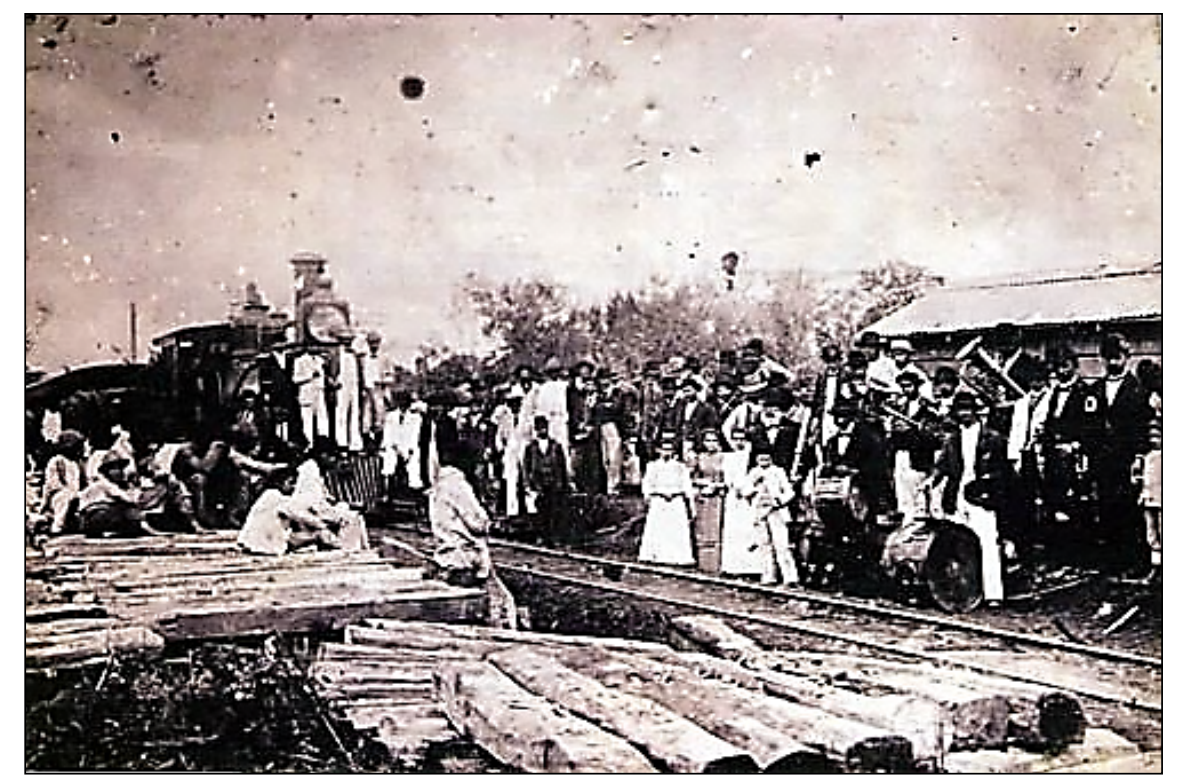

Fonte: http://www.blogdomadeira.com.br/2012/05/120-anos-da-ferrovia-em-varginha/ Acesso em 09/03/2018.

Contudo, em 1892, com a chegada da ferrovia, a função comercial de Varginha se ampliou, beneficiando também as populações rurais de outros municípios vizinhos em que a ferrovia não passava. Assim, Varginha tornou-se ponto estratégico de comercialização e escoamento de produtos oriundos não apenas da cidade, mas também de locais vizinhos, especialmente o café (Ávila, 1983, p. 14).

Varginha tomou nova forma com a chegada da estrada de ferro, que contribuiu para o crescimento urbano e econômico da localidade: crescimento urbano devido à valorização do espaço próximo à ferrovia; crescimento econômico por conta da expansão do transporte de mercadorias que passavam pela estação, especialmente o café.

Sobre o crescimento urbano, é possível verificar tal crescimento por meio das palavras de Ávila:

Uma primeira manifestação mais declarada todavia, da setorização urbana é a que começa a esboçar-se por volta de 1892 com a chegada da estrada de ferro e a inauguração da estação ferroviária, determinando não só a expansão da cidade para as faixas de terreno que tangenciam a ferrovia, como igualmente a concentração ali de atividades mais de perto favorecidas pelo novo meio de transporte e comunicação (Ávila, 1983, p. 5).

As consequências da passagem da ferrovia por Varginha não restringiram-se apenas à década de sua inauguração, se estendendo para os anos iniciais do século xx. Dessa forma, é possível entender o crescimento econômico associado ao crescimento urbano:

Nas vias de acesso que surgem balizando ambos os lados do leito da estrada de ferro... aparecem, em inícios deste século [século XX], construções de porte e tipo inteiramente 
novos para a cidade, como galpões e armazéns de depósito, nos quais se instalam máquinas de beneficiamento de café, e estabelecimentos destinados ao comércio atacadista e de exportação desse produto, bem como algumas pequenas indústrias manufatureiras e de transformação, principalmente de laticínios e outros produtos alimentícios (Ávila, 1983, p. 6).

No ano de 1907, a Companhia Estrada de Ferro Muzambinho, localizada no Rio de Janeiro, vendeu para o Estado de Minas Gerais a concessão da ferrovia. O valor foi de 12 mil contos de réis, uma quantia muito alta em dinheiro, incomparável com qualquer bem registrado no município de Varginha. No ano de 1908, pelos mesmos 12 mil contos de réis, o Estado de Minas Gerais transmitiu para a Fazenda Federal da República as concessões federais e estaduais da Estrada de Ferro.

Por meio da tabela 5 descrita abaixo, é possível analisar dados de receita e despesa dos ramais da ferrovia Muzambinho.

A Fluvial descrita na tabela 5 refere-se à estação fluvial da Companhia Muzambinho, localizada em Varginha. Exceto no ano de 1906, todos os saldos da Companhia foram negativos. Considerando os ramais, de acordo com o que mostra a tabela, é possível dizer que o de Três Corações (até a Fluvial) era o único que apresentava as receitas maiores que as despesas. Da Fluvial até Areado e o ramal de Campanha apresentavam sempre receitas menores que as despesas. O saldo total negativo das contas da Companhia não se devia ao ramal de Três Corações até a estação Fluvial. A partir daquele ponto é que os valores das receitas passavam a diminuir e as despesas aumentavam.

O trecho de Três Corações até a estação Fluvial, em Varginha, ter sido o único que apresentou valores de receitas maiores que os de despesas pode ser explicado pela dinâmica à qual o município de Varginha passava: desenvolvimento da cafeicultura e do transporte de mercadorias por meio da ferrovia, surgimento de casas comerciais, instalação de instituições bancárias, as primeiras fábricas. Tais elementos, juntamente com a estrada de ferro, contribuíam não apenas com o processo de formação e desenvolvimento de Varginha, mas também de municípios e distritos próximos das terras varginhenses.

Varginha, um município do interior do Brasil, em formação, com uma estação ferroviária em fins do século XIX, possuía um meio fundamental para o avanço de seu crescimento urbano e econômico, ainda que de forma particular. A figura 2 retrata a estação ferroviária na década de 1920.

\section{Considerações finais}

Na passagem do século XIX para o século xx, em que diferentes regiões do Brasil passaram por crescimento econômico e urbano, vale ressaltar que tal crescimento foi possível com auxílio do novo serviço que chegava nas mais diversas localidades: a estrada de ferro.

Transporte de pessoas e de mercadorias, meio de comunicação social, geração de trabaIho, ${ }^{29}$ auxílio na promoção de crescimento urbano e econômico, essas são as consequências que a ferrovia levava às localidades por onde passava. 


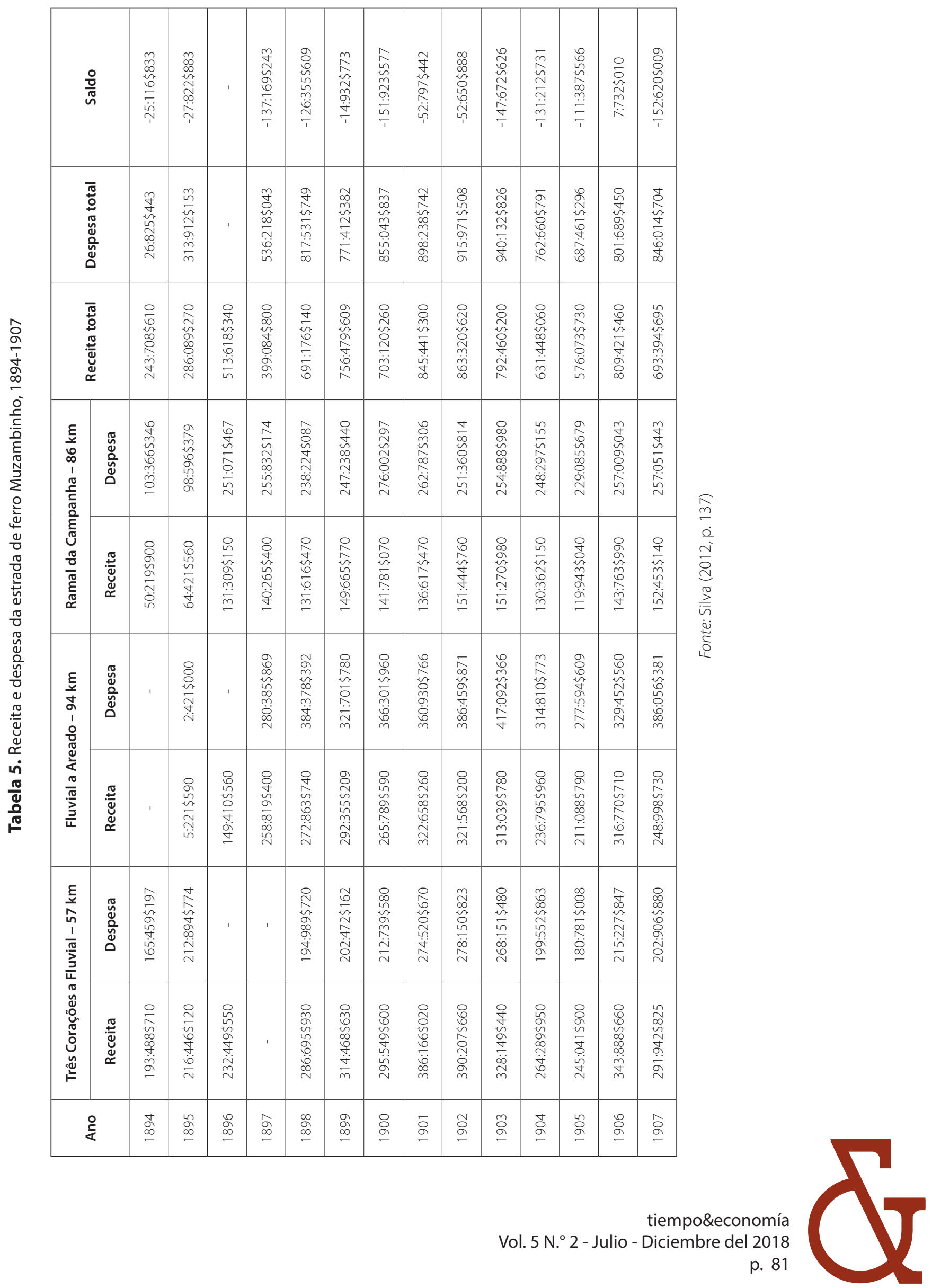


Figura 2. Estação ferroviária da Estrada de Ferro Muzambinho em Varginha, 1920

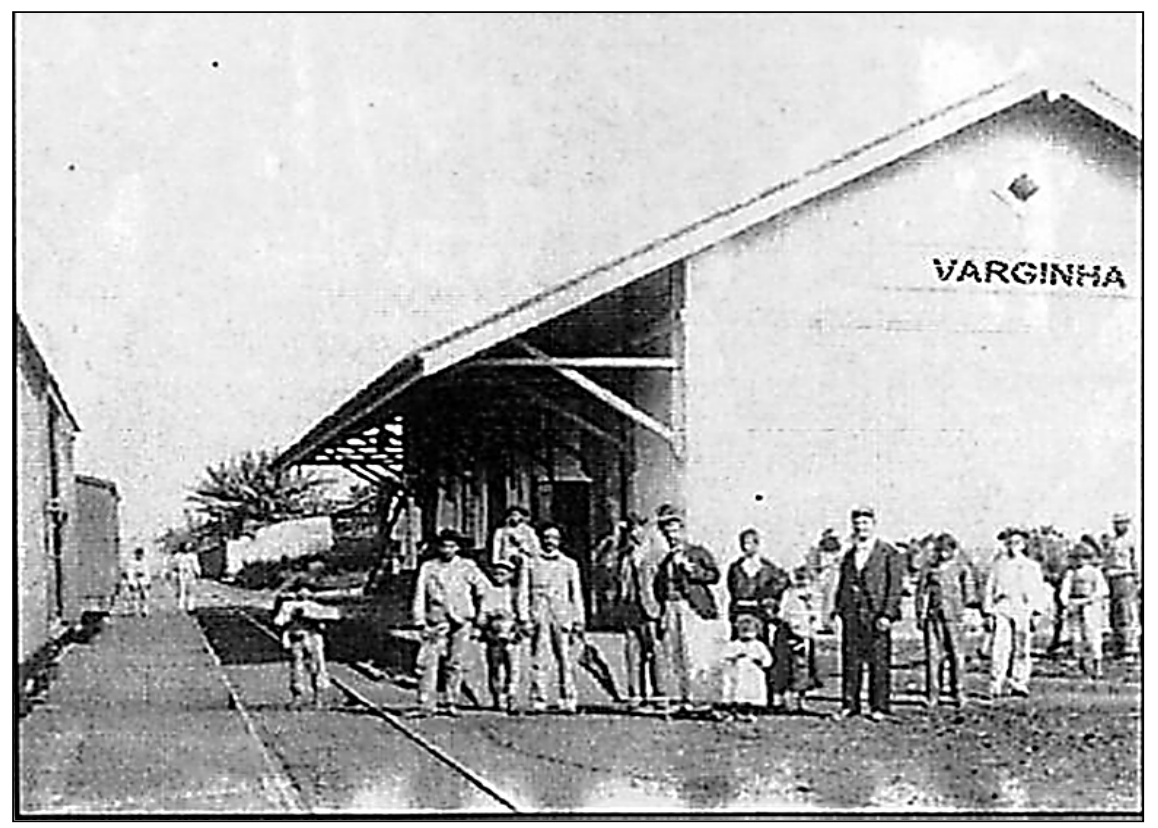

Fonte: http://www.estacoesferroviarias.com.br/rmv_cruz_jureia/fotos/varginha201.jpg Acesso em: 09/03/2018

O Sul de Minas Gerais, região do Brasil que durante grande parte de sua história -época da economia do ouro- teve como atividade principal a produção de gêneros de abastecimento para outras regiões do país, como a Corte, ganhou nova forma com a chegada da estrada de ferro nos municípios que compunham a localidade. Assim como ocorreu na região de São Paulo, café e ferrovias passaram a ser dois elementos importantes para o crescimento econômico e urbano sul-mineiro, embora tal crescimento tenha ocorrido de forma particular, com algumas limitações que marcam os municípios do interior dos países.

É importante mencionar que as ferrovias sul-mineiras não transportavam apenas café, ainda que o produto, com o passar do tempo, passasse por uma considerável expansão nas cifras de mercadorias exportadas ${ }^{30}$.

No Sul de Minas Gerais, café e ferrovias foram responsáveis pelo surgimento de novos municípios entre o final do século xix e o início do século xx, como é o caso de Varginha, que em dezembro de 1882 contou com a primeira reunião da Câmara Municipal de vereadores.

Dentre as transformações às quais o novo município passou -a introdução do café, o surgimento de casas comerciais, a chegada das instituições bancárias e das primeiras fábricas- este artigo destacou a ferrovia porque é um serviço que pode ser considerado uma inovação para a época e para o contexto de formação de Varginha, pois uma estação da estrada de ferro foi inaugurada na cidade dez anos depois de sua emancipação, e auxiliou na promoção de crescimento econômico e urbano para o município.

30 Sobre o percentual do valor da produção de café no conjunto das exportações mineiras, entre 1899 e 1924, conferir: Alvim (1929) apud Pires (2009, p. 35). 
O crescimento econômico pode ser destacado pensando-se nas mercadorias que eram transportadas pela ferrovia, especialmente o café, e na geração de trabalho que o novo serviço proporcionou devido a estação inaugurada em Varginha. Os produtores de café e de outras culturas no município contavam com um meio de transporte que levaria suas mercadorias a longas distâncias em tempo menor, auxiliando na dinâmica da produção.

O crescimento urbano pode ser ressaltado porque a ferrovia fez valorizar o que estava à sua volta e, os novos terrenos, as novas construções de casas, os galpões e armazéns, faziam que se ampliasse o espaço urbano varginhense, em tamanho e diversidade.

Crescimento econômico e urbano específicos, com particularidades do interior do Brasil, pois Varginha não era um centro econômico, ou um grande produtor de café, nem abrigava casas comerciais e fábricas de grande porte, entretanto, aos poucos, sua paisagem era modificada, transformação urbana que, de certa forma, contribuía para transformações na economia local.

\section{Referências}

Fontes manuscritas

Atas da Câmara Municipal de Varginha (ACMV) referentes às décadas de 1880 e 1890 - depositadas no Museu Municipal de Varginha (MMV).

Inventário de Matheus Tavares da Silva, 1905, caixa 598, documento 23 - presente no Arquivo do Judiciário da Comarca de Varginha (AJCV).

Registros de Imóveis do período de 1882 até 1920 - arquivadas no Cartório de Registros de Imóveis da cidade de Varginha (CRIV).

Fontes impressas

Questionários sobre as condições da agricultura de 176 municípios no Estado de Minas Geraes, inspecionados de 9 e Abril de 1910 a 30 de Novembro de 1913. Serviço de inspeção e defesa agrícola de Minas Gerais (Ministério da Agricultura, Industria e Commercio). Rio de Janeiro: Typografia do Serviço de Estatística, 1913.

Veiga, B. S. (1874). Almanach Sul-Mineiro para 1874. Campanha: Typographia do Monitor Sul-Mineiro.

Veiga, B. S. (1884). Almanach Sul-Mineiro para 1884. Campanha: Typographia do Monitor Sul-Mineiro.

Referências bibliográficas

Almeida, R. B. (2009). Traços da história econômica da Bahia no último século e meio. RDE - Revista de Desenvolvimento Econômico, XI(19), 82-101.

Ávila, A. (1983). Varginha: formação e evolução. Fundação João Pinheiro , 13(7/8), 2-18.

Blasenhein, P. (1996). As Ferrovias de Minas Gerais no século dezenove. Locus - Revista de História, 2(2), 81-110. 
Bueno, R. (2012). Borracha na Amazônia: As cicatrizes de um ciclo fugaz e o início da industrialização. Porto Alegre: Quattro Projetos.

Cano, W. (2012). Da Década de 1920 à de 1930: Transição Rumo à Crise e à Industrialização no Brasil. EconomiA, 13(3b), 897-916.

Cano, W. (1975). Raízes da Concentração Industrial em São Paulo. Tese, Doutorado em Ciências Econômicas. Instituto de Filosofia e Ciências Humanas, Universidade Estadual de Campinas.

Correa, R. (2012). Café y ferrocarriles en Colombia: los trenes santandereanos, 1869-1990. Bogotá: Colegio de Estudios Superiores de Administración - CESA.

Costa, M. L., Costa, M. L. y Lacerda, P. H. (2015). Album Chorographico Municipal do Estado De Minas Gerais (1927) e o Patrimônio Ferroviário: Estrada de Ferro Muzambinho (1898-1911) Minas Gerais, Brasil. Em Atas do VI Simpósio Luso-Brasileiro de Cartografia Histórica, 4 a 7 de novembro de 2015, Braga.

Dean, W. (1977). A Industrialização de São Paulo, 2 ed. São Paulo: Difel.

Faleiros, R. N. y Nunes, I. (orgs.) (2011). Sistemas de transportes e formações econômicas regionais: Brasil y Argentina (vol. 1). Vitória: EDUFES.

Ferreira, N. S. (2017). Elite Agrária e processo de Urbanização: o município de Varginha-MG, 18821920. Dissertação, Mestrado em História Econômica, Faculdade de Filosofia, Letras e Ciências Humanas, Universidade de São Paulo.

Ferreira, S. M. (2005). Federalismo, economia exportadora e representação política: o Amazonas na República Velha, 1889-1914. Tese, Doutorado em História Econômica. Instituto de Economia, Universidade Estadual de Campinas.

Fishlow, A. (1965). American railroads and the transformation of the Ante-Bellum economy. Cambridge, Mass: Harvard University Press.

Fogel, R. W. (1964). Railroads and American economic growth: Essays in econometric history. Baltimore: The Johns Hopkins Press.

Furtado, C. (1963). Formação Econômica do Brasil. Brasília: Editora Universidade de Brasília.

Godoy, M. y Barbosa, L. (2008). Uma outra modernização. Transportes em uma província não exportadora - Minas Gerais, 1850-1870. Economia e Sociedade, Campinas, 17, 2(33), 159186.

Godoy, M. Horta, M. y Barbosa, L. (2017). Entre o conservadorismo orçamentário e o desenvolvimento regional: finanças públicas e infraestrutura de transportes em Minas Gerais na Primeira República. América Latina en la historia económica, 24(2), 148-200.

Goulart F., A. y Queiroz, P. R. C. (Orgs.). (2011). Transportes e formação regional: contribuições à história dos transportes no Brasil. Dourados: Ed. UFGD.

Herrlein Jr., R. (2000). Rio Grande do Sul, 1889-1930: Um outro capitalismo no Brasil meridional? Tese, Doutorado em História Econômica. Instituto de Economia, Universidade Estadual de Campinas.

Hobsbawm, E. J. (2016). A Era dos Impérios, 1875-1914. 20 ed. São Paulo: Paz e Terra. 
Iglésias, F. (1982). Política Econômica do Estado de Minas Gerais, 1889-1930. Em N. Monteiro. (Org). Seminário de Estudos Mineiros: A República Velha em Minas. Belo Horizonte: UFMG.

Kuntz F., S. (Org). (2015). História mínima de la expansión ferroviaria em América Latina. México, D.F.: El Colegio del México.

Lacerda, S. M. (2009). Ferrovias Sul-Americanas: a integração possível. Revista do BNDES, 16( 31), 185-214.

Lamounier, M. L. (2012). Ferrovias e mercado de trabalho no Brasil do século XIX. São Paulo: Edusp.

Lanna, A. L. D. (1985). A Transformação do Trabalho - A passagem para o trabalho livre na Zona da Mata Mineira (1870-1920). Dissertação, Mestrado em História. Instituto de Filosofia e Ciências Humanas, Universidade Estadual de Campinas.

Lenharo, A. (1993). As tropas da moderação - O abastecimento da Corte na formação política do Brasil: 1808-1842. Rio de Janeiro: Secretaria Municipal de Cultura, Turismo e Esportes, Departamento Geral de Documentação e Informação Cultural, Divisão de Editoração.

Lima, J. H. (1977). Café e Indústria em Minas Gerais, 1870-1920. Dissertação, Mestrado em Economia. Instituto de Filosofia e Ciências Humanas, Universidade Estadual de Campinas.

Lopes, L. S. (2005). Sob os olhos de São Sebastião. A cafeicultura e as mutações da riqueza em Ribeirão Preto 1849-1900. Tese, Doutorado em História Econômica. Faculdade de Filosofia, Letras e Ciências Humanas, Universidade de São Paulo.

Maia, A. C. (2009). Encontros e despedidas - Ferrovias e ferroviários de Minas. Belo Horizonte: Argvmentvm.

Marcondes, R. L. y Oliveira, J. H. (2013). Trocando de mãos: o mercado de imóveis rurais em Ribeirão Preto, 1874-1930. Economia e Sociedade, 22(1), 263-285.

Martins, M. L. (2011). Uma história da navegação a vapor no Sul de Minas, 1880-1960. Diálogos, $15(2), 409-436$.

Martins, M. L. y Souza, A. S. (2012). Notas sobre as Propriedades Rurais de Alfenas, MG: décadas de 1860-1880. Em A. M. Saes e M. L. Martins (Orgs.). Sul de Minas em Transição - A formação do Capitalismo na passagem para o século 20 (pp. 149-174). São Paulo: Edusc.

Martins, M. L. (2016). A marcha do café no Sul de Minas, décadas de 1880-1920: Alfenas, Guaxupé, Machado e Três Pontas. Em A. M. Saes, M. L. Martind e T. Gambi (orgs.), Sul de Minas em Urbanização: Modernização Urbana no início do século XX (pp. 141-172). São Paulo: Alameda.

Mello, J. M. C. (1986). O capitalismo tardio. São Paulo: Brasiliense.

Mello, Z. M. C. (1985). Metamorfoses da Riqueza - São Paulo, 1845-1895. São Paulo: HUCITEC.

Nunes, I. (2007). Integração Ferroviária Sul-Americana: por que não anda esse trem? Cadernos PROLAM/USP, 2(7), 97-124.

Oliveira, P. R. (2007). Entre rios e trilhos - As possibilidades de integração econômica de Goiás na Primeira República. Dissertação, Mestrado em História e Cultura. Faculdade de História, Direito e Serviço Social. Franca: UNESP. 
Paiva, C. A. y Godoy, M. M. (2002). Território de contrastes: Economia e sociedade das Minas Gerais do século XIX. X Seminário sobre a Economia Mineira. Anais do evento. Diamantina: Cedeplar - UFMG.

Pires, A. (2004). Café, Finanças e Bancos: Uma Análise do Sistema Financeiro da Zona da Mata de Minas Gerais, 1889-1930. Tese, Doutorado em História Econômica. Faculdade de Filosofia, Letras e Ciências Humanas, Universidade de São Paulo.

Pires, A. (2009). Café, Finanças e Indústria: Juiz de Fora (1889/1930). Juiz de Fora: Edições Funalfa.

Queiroz, P. R. (2004). Uma ferrovia entre dois mundos: a E. F. Noroeste do Brasil na primeira metade do século 20. Bauru, SP: EDUSC.

Saes, A M. (2008). Conflitos do Capital: Light versus CBEE na Formação do Capitalismo Brasileiro, 1898-1927. Tese, Doutorado em História Econômica. Instituto de Economia, Universidade Estadual de Campinas.

Saes, A. M. et al. (2010). Sul de Minas em transição: ferrovias, bancos e indústrias na constituição do capitalismo na passagem do século XIX para o século XX. Em XIV Seminário sobre a Economia Mineira. Diamantina: Cedeplar-UFMG.

Saes, A. M., Gambi, T. F. y Curi, L. F. (2016). O processo de urbanização no Sul de Minas em transição: uma proposta de interpretação. Em A. M. Saes, M. Martins y T. Gambi (orgs.). Sul de Minas em Urbanização: modernização urbana no início do século XX (pp. 23-53). São Paulo: Alameda.

Saes, A. M., Cosentino, D. V. y Gambi, T. F. (2012). Sul de Minas em Transição: opção por uma regionalização como ponto de partida. Em A. M. Saes y M. Martins (orgs.). Sul de Minas em Transição - A formação do Capitalismo na passagem para o século 20 (pp. 13-36). São Paulo: Edusc.

Saes, F. A. M. (1981). As ferrovias de São Paulo: 1870-1914. São Paulo: Hucitec.

Sales, J. R. (2003). Espírito Santo da Varginha (MG), 1763-1920. Varginha: Gráfica Editora Sul Mineira.

Santos, W. L. (2009). A Estrada de Ferro Oeste de Minas: São João del Rei, 1877-1898. Dissertação, Mestrado em História. Instituto de Ciências Humanas e Sociais, Universidade Federal de Ouro Preto.

Silva, M. P. (2012). De gado a café: as ferrovias no sul de Minas Gerais, 1874-1910. Dissertação, Mestrado em História Econômica. Faculdade de Filosofia, Letras e Ciências Humanas, Universidade de São Paulo.

Silva, M. P. (2012a). Tem Café nesse Trem? As Ferrovias no Sul de Minas Gerais (1874-1910). In: Saes, A. M; Martins, M. L. (Orgs.). Sul de Minas em Transição - A formação do Capitalismo na passagem para o século 20 (pp. 177-207). São Paulo: Edusc.

Silva, M. P. (2018). Nos trilhos da incerteza: A Rede Sul Mineira no contexto ferroviário brasileiro, 1910-1934. Tese, Doutorado em História Econômica. Faculdade de Filosofia Letras e Ciências Humanas, Universidade de São Paulo.

Silva, S. (1976). Expansão Cafeeira e Origens da Indústria no Brasil. São Paulo: Alfa Omega. 
Vieira, E. J. (2015). Produção, comércio e acumulação de riqueza em um município escravista mineiro: Lavras/MG, 1870-1888. Dissertação, Mestrado em História Econômica. Faculdade de Filosofia, Letras e Ciências Humanas, Universidade de São Paulo.

Wirth, J. (1982). O Fiel da Balança: Minas Gerais na Federação Brasileira, 1889-1937. Rio de Janeiro: Paz e terra. 